\title{
DAYA TERIMA KERIPIK KANGKUNG BELERANG DENGAN PENGGORENGAN MENGGUNAKAN MINYAK CURAH
}

\author{
Jane Melita Keliat ${ }^{1}$, Dewi Novina Sukapiring ${ }^{2}$, Winny Iftari $^{3}$ \\ ${ }^{1}$ Email: jane310189@gmail.com, \\ ${ }^{2}$ Email: dewi.novina88@gmail.com \\ 3Email: iftari@kemenperin.go.id \\ 1,2 Program Studi Agribisnis, Universitas Nahdlatul Ulama Sumatera Utara, Jl. H. Abdul \\ Manaf Lubis No.2 Gaperta Ujung, Medan, Sumatera Utara \\ ${ }^{3}$ Politeknik Teknologi Kimia Industri Medan. Jl. Menteng VII, Medan, Sumatera Utara
}

\begin{abstract}
ABSTRAK
Peneletian tentang Daya Terima Keripik Kangkung Belerang Dengan Penggorengan Menggunakan Minyak Curah telah dilakukan pada Bulan April - Agustus 2018. Penelitian ini bertujuan untuk mengetahui kandungan analisis kimia pada keripik kangkung belerang dengan menggunakan minyak curah meliputi, kadar air, kadar abu, kadar sulfur, kadar lemak, kadar karbohidrat, kadar protein dan bilangan peroksida dan untuk mengetahui masa simpan, uji hedonik meliputi aroma, rasa, tekstur dan warna. Kadar air, kadar abu, kadar sulfur, kadar lemak, kadar karbohidrat, kadar protein dan bilangan peroksida meliputi $0,15 \% ; 87,64 \% ; 54,25 \% ; 6,75 \% ; 5,01 \% ; 14,31 \%$ dan $7,18 \mathrm{meq} / \mathrm{kg}$. Bilangan peroksida pada kondisi terpapar matahari meningkat yakni hari ke-0 sebesar 7,18 meq/kg dengan tekstur keripik kangkung belerang yang renyah dan hari ke-18 sebesar 59,15 meq/kg dengan tekstur keripik kangkung belerang tidak renyah dan tengik. Uji hedonik yang dilakukan oleh 20 panelis tidak terlatih menunjukkan bahwa aroma, rasa dan warna disukai dengan tekstur yang renyah.
\end{abstract}

Kata kunci: analisis kimia, daya terima, kangkung belerang

\section{PENDAHULUAN}

Kangkung belerang merupakan kangkung yang dapat tumbuh dengan dua aliran air meliputi air tawar dan air yang mengandung kadar belerang. Kangkung belerang merupakan hasil pertanian yang menjadi unggulan masyarakat di Desa Semangat Gunung, Kabupaten Karo. Kangkung belerang memiliki cita rasa yang unik dibandingkan jenis kangkung lainnya. Hal ini lah yang menjadikan kangkung belerang banyak digemari masyarakat khususnya di Sumatera Utara.

Pengolahan hasil pertanian diperlukan untuk meningkatkan nilai tambah dari komoditas kangkung belerang. Salah satunya adalah olahan keripik. Olahan keripik merupakan salah satu produk pangan yang paling banyak digemari masyarakat. Keripik banyak digemari karena memiliki rasa yang renyah, enak dan tahan lama dan praktis (Sulistyowati 2010).

Kelompok ibu-ibu di Desa Semangat Gunung, Kabupaten Karo, Sumatera Utara mendirikan usaha "Keripik Kangkung Belerang, Sibayak" sebagai hasil olahan pangan kangkung belerang. Pada masa penggorengan, ibu-ibu di Desa Semangat Gunung memilih menggunakan minyak curah, karena suhu yang rendah di daerah tersebut sehingga minyak curah lebih mudah membeku daripada minyak goreng 
kemasan. Hingga saat ini, belum dilakukan pengujian terhadap analisis kimia pada produk keripik kangkung belerang serta daya simpan keripik kangkung belerang dengan menggunakan minyak curah.

Analisis kimia pada produk pangan diperlukan untuk mengetahui kandungan bahan yang terdapat dalam keripik. Sifatsifat sensoris penting yang menentukan penilaian seseorang terhadap produk yang digoreng adalah warna, rasa, aroma, dan tekstur. Untuk itu, perlu dilakukan penelitian tentang Daya Terima Keripik Kangkung Belerang Dengan Penggorengan Menggunakan Minyak Curah.

\section{METODE PENELITIAN}

Penelitian ini dilaksanakan di laboratorium Biokimia, Fakultas Matematika dan Ilmu Pengetahuan Alam, Universitas Sumatera Utara.

\section{Prosedur Penelitian}

\section{Pembuatan Keripik Kangkung Belerang}

Prosedur pembuatan keripik kangkung belerang seperti bagan di bawah ini:

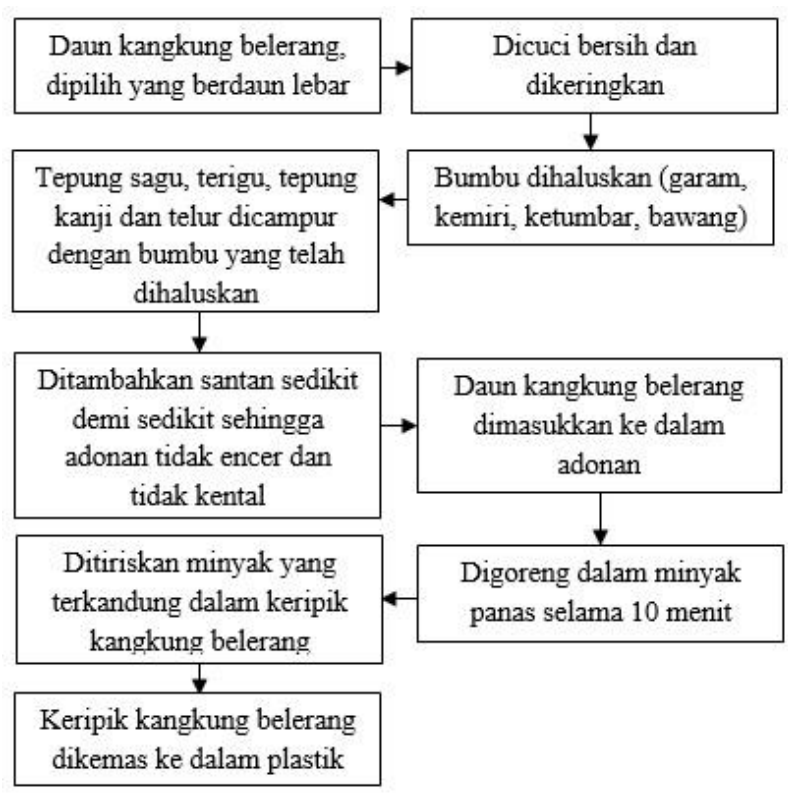

\section{Kadar Abu Total (Dry Ashing)}

Pengukuran kadar abu total dilakukan dengan metode drying ash. Sampel sebanyak $3 \mathrm{~g}$ ditimbang pada cawan yang sudah diketahui bobotnya. Lalu diarangkan di atas nyala pembakaran dan diabukan dalam tanur pada suhu $550^{\circ}$ $\mathrm{C}$ hingga pengabuan sempurna. Setelah itu didinginkan dalam eksikator dan ditimbang hingga diperoleh bobot tetap. Perhitungan kadar abu dilakukan dengan membandingkan berat abu dan berat sampel dikali $100 \%$.

\section{Kadar Air Total (Termogravimetri)}

Pengukuran kadar air total dilakukan dengan metode termogravimetri (metode oven). Sampel sebanyak $2 \mathrm{~g}$ ditimbang pada cawan yang sudah diketahui bobotnya lalu dikeringkan pada oven suhu $105^{\circ} \mathrm{C}$ selama 3 jam. Setelah itu didinginkan dalam eksikator dan ditimbang hingga diperoleh bobot tetap. Perhitungan kadar air diperoleh dengan membandingkan bobot sampel sebelum dikeringkan dan bobot yang hilang setelah dikeringkan dikali $100 \%$.

\section{Kadar Lemak Total}

Pengukuran kadar lemak total dilakukan dengan metode Soxhletasi. Sampel ditimbang sebanyak $2 \mathrm{~g}$, lalu dimasukkan ke dalam kertas saring yang dialasi kapas. Kertas saring yang berisi sampel disumbat dengan kapas, lalu dikeringkan dalam oven pada suhu tidak lebih dari $80^{\circ} \mathrm{C}, \pm 1$ jam dan dimasukkan ke dalam alat Sokhlet yang telah dihubungkan dengan labu lemak berisi batu didih yang telah dikeringkan dan telah diketahui bobotnya. Setelah itu, diekstrak dengan pelarut petroleum eter selama lebih kurang 6 jam. Petroleum eter disulingkan dan ekstrak lemak dikeringkan dalam oven pada suhu $105^{\circ} \mathrm{C}$ lalu didinginkan dan ditimbang hingga bobot tetap. Perhitungan kadar lemak dilakukan dengan membandingkan berat lemak dan berat sampel dikali $100 \%$. 


\section{Kadar Protein Total (Kjeldahl)}

Pengukuran kadar abu total dilakukan dengan metode Kjehdahl. Sampel yang telah dihaluskan ditimbang 200-500 mg lalu dimasukkan ke dalam labu Kjeldahl. Ditambahkan $10 \mathrm{~mL}$ asam sulfat pekat padat dan $5 \mathrm{~g}$ katalis (campuran $\mathrm{K} 2 \mathrm{SO} 4$ dan $\mathrm{CuSO} 4.5 \mathrm{H} 2 \mathrm{O} 8$ : 1) lalu dilakukan destruksi (dalam lemari asam) hingga cairan berwarna hijau jernih. Setelah dingin larutan tersebut diencerkan dengan aquadest hingga $100 \mathrm{~mL}$ dalam labu ukur. Larutan tersebut dipipet $10 \mathrm{~mL}$ dan dimasukkan ke dalam alat distilasi Kjeldahl lalu ditambah $10 \mathrm{~mL} \mathrm{NaOH} \mathrm{30 \%}$ yang telah dibakukan oleh larutan asam oksalat. Distilasi dijalankan selama kirakira 20 menit dan distilatnya ditampung dalam erlenmeyer yang berisi $25 \mathrm{~mL}$ larutan $\mathrm{HCl} 0,1 \mathrm{~N}$ yang telah dibakukan oleh boraks (ujung kondensor harus tercelup ke dalam larutan $\mathrm{HCl}$ ). Lalu kelebihan $\mathrm{HCl}$ dititrasi dengan larutan $\mathrm{NaOH} 0,1 \mathrm{~N}$ dengan indikator campuran bromkresol hijau dan metil merah. Perhitungan kadar protein total dilakukan dengan perhitungan:

Kadar Nitrogen $(\%)=\frac{(\mathrm{Va} . \mathrm{Na}-\mathrm{Vb} . \mathrm{Nb}) \times 14 \times 100 / 10}{\mathrm{~W}} \times 100 \%$

\section{Kadar Karbohidrat Total}

Pengukuran kadar karbohidrat total dalam sampel dihitung berdasarkan perhitungan

(dalam \%), dengan menggunakan rumus sebagai berikut:

$\%$ Karbohidrat $=100 \%-\%($ protein + lemak + abu + air)

\section{Kadar Sulfur}

0,5 g sampel dimasukkan dalam 250 mL erlenmeyer, $10 \mathrm{~mL}$ larutan HCL $4 \mathrm{~N}$ ditambahkan dan diaduk lalu ditambahkan $100 \mathrm{~mL}$ air dan panaskan sampai mendidih. $\mathrm{BaCl} 2(10 \mathrm{~mL} \mathrm{BaCl} 20,5 \mathrm{~N}$ dalam $50 \mathrm{~mL}$ air) ditambahkan sambil diaduk. Biarkan endapan dan tambahkan 1 tetes $\mathrm{BaCl} 2$. Jika terbentuk endapan putih, penambahan larutan dihentikan. Masukkan endapan di waterbath selama 1 jam. Saring dengan kertas saring yang bersih. Cuci lalu keluarkan dalam cawan poselin dan keringkan dalam oven. Hapus bahan yang diperoleh pada suhu 700-1100 OC selama sekitar 3 jam. Didinginkan dalam desikator dan pindahkan ke suhu kamar. Timbang dan tentukan kandungan sulfur dalam sampel.

\section{Bilangan Peroksida}

Bilangan peroksida ditentukan dengan prosedur sebagai berikut: Minyak sebanyak $10 \mathrm{~g}$ dimasukkan ke dalam Erlenmeyer tertutup dan ditambahkan 30 $\mathrm{ml}$ pelarut campuran asam asetat glacial : kloroform (3:2 v/v). Setelah minyak larut sempurna ditambahkan 0,5 ml larutan $\mathrm{KI}$ jenuh dan dibiarkan 1 menit sambil dikocok, kemudian ditambahkan $30 \mathrm{ml}$ aquades. Iodium yang dibebaskan oleh peroksida dititrasi dengan larutan standar natrium tiosulfat (Na2S2O3) $0.1015 \mathrm{~N}$ dengan indikator amilum sampai warna biru hilang. Bilangan peroksida dinyatakan dengan rumus perhitungan sebagai berikut:

$$
\text { Bilangan Peroxida }=\frac{(\mathrm{S}-\mathrm{B}) \times \mathrm{N} \times 1000}{(\mathrm{meq} / \mathrm{kg}) \text { berat sampel }(\mathrm{g})}
$$

$\mathrm{S}=$ titrasi sampel; $\mathrm{B}=$ titrasi blanko, $\mathrm{N}=$ Normalitas Na2S2O3

\section{Uji Hedonik}

Uji hedonik dilakukan oleh 20 panelis tidak terlatih berdasarkan penilaian aroma, warna, rasa (sangat suka, suka, kurang suka, tidak suka, sangat tidak suka) dan penilaian tekstur (sangat renyah, renyah, kurang renyah, tidak renyah, sangat tidak renyah).

\section{HASIL}

Hasil analisis kimia kangkung belerang segar dan keripik kangkung 
belerang dengan menggunakan minyak goreng curah dapat dilihat pada Tabel 1.

Tabel 1 Analisis kimia kangkung belerang segar dan sesudah keripik kangkung belerang dengan penggorengan menggunakan minyak goreng curah

\begin{tabular}{lcc}
\hline \multicolumn{1}{c}{ Komponen } & Sebelum Penggorengan & Sesudah Penggorengan \\
\hline Air & $37,22 \%$ & $0,15 \%$ \\
Abu & $38,58 \%$ & $87,64 \%$ \\
Sulfur & $62,84 \%$ & $54,25 \%$ \\
Lemak & $5,64 \%$ & $6,75 \%$ \\
Protein & $12,47 \%$ & $14,31 \%$ \\
Karbohidrat & $1,43 \%$ & $5,01 \%$ \\
Peroksida & - & $11,18 \mathrm{meq} / \mathrm{kg}$ \\
\hline
\end{tabular}

Pendugaan umur simpan keripik kangkung belerang yang terpapar cahaya matahari dengan perubahan jumlah bilangan peroksida dan penilaian organoleptik yang terpapar cahaya matahari pada saat penyimpanan dapat dilihat pada Tabel 2.

Tabel 2 Perubahan bilangan peroksida dan penilaian organoleptik pada kondisi terpapar cahaya matahari

\begin{tabular}{ccc}
\hline Hari & Bilangan Peroksida $(\mathrm{meq} / \mathrm{kg})$ & Penilaian Organoleptik \\
\hline 0 & 7,18 & Renyah \\
3 & 31,18 & Renyah \\
6 & 51,66 & Renyah \\
9 & 51,69 & Renyah \\
12 & 55,57 & Renyah \\
15 & 57,54 & Tidak renyah, tengik \\
18 & 59,15 & Tidak renyah, tengik \\
\hline
\end{tabular}

Hasil uji hedonik terhadap aroma, rasa, warna dan tekstur keripik kangkung belerang dengan penggorengan menggunakan minyak curah yang dilakukan oleh 20 panelis tidak terlatih dapat dilihat pada Tabel 3 dan Tabel 4.

Tabel 3 Uji hedonik berdasarkan aroma, rasa dan warna keripik kangkung belerang dengan penggorengan menggunakan minyak curah

\begin{tabular}{lccccc}
\hline Penilaian & Sangat Suka & Suka & $\begin{array}{c}\text { Kurang } \\
\text { Suka }\end{array}$ & Tidak Suka & $\begin{array}{c}\text { Sangat } \\
\text { Tidak Suka }\end{array}$ \\
\hline Aroma & $5 \%$ & $85 \%$ & $10 \%$ & $0 \%$ & $0 \%$ \\
Rasa & $5 \%$ & $85 \%$ & $10 \%$ & $0 \%$ & $0 \%$ \\
Warna & $0 \%$ & $80 \%$ & $15 \%$ & $5 \%$ & $0 \%$ \\
\hline
\end{tabular}

Tabel 4 Uji hedonik berdasarkan tekstur keripik kangkung belerang dengan penggorengan menggunakan minyak curah

\begin{tabular}{lccccc}
\hline Penilaian & $\begin{array}{c}\text { Sangat } \\
\text { Renyah }\end{array}$ & Renyah & $\begin{array}{c}\text { Kurang } \\
\text { Renyah }\end{array}$ & $\begin{array}{c}\text { Tidak } \\
\text { Renyah }\end{array}$ & $\begin{array}{c}\text { Sangat Tidak } \\
\text { Renyah }\end{array}$ \\
\hline Tekstur & $0 \%$ & $80 \%$ & $15 \%$ & $5 \%$ & $0 \%$ \\
\hline
\end{tabular}




\section{PEMBAHASAN}

Dari hasil pengamatan pada tabel 1dapat diketahui bahwa kadar air pada kangkung segar (sebelum penggorengan) sebesar $37,22 \%$ lebih besar dibandingkan dengan setelah digoreng. Hal ini dikarenakan kadar air akan menghilang pada proses penggorengan yang memakai minyak goreng dengan suhu diatas 1000 C. Semakin tinggi suhu yang digunakan maka semakin besar air yang menguap, sehingga air yang terkandung dalam keripik buah akan berkurang (Tumbel dan Manurung 2017).

Kadar abu setelah digoreng mengalami peningkatan daripada sebelum dilakukan penggorengan yakni sebesar $87,64 \%$, hal ini dikarenakan pada proses penggorengan kadar air dalam bahan mengalami penurunan sedangkan massa bahan tetap sehingga persentase bahan yang tidak berpengaruh terhadap suhu akan mengalami pengingkatan, dikarenakan faktor pembaginya. Menurut Asmawit dan Hidayati (2014), kadar abu yang sangat tinggi mengindikasikan bahwa telah terjadi kontaminan bahan oleh alat karena adanya gesekan selama proses. Menurut Winarno (2004), kadar abu dalam makanan berasal dari zat anorganik sisa pembakaran yang terdiri dari bahan mineral seperti fosfor, kalsium, belerang, sodium dan bahan lainnya.

Hal yang menarik dalam data diatas ditemukan bahwa kandungan sulfur sebelum dan sesudah mengalami penurunan sebesar $8,59 \%$, hal ini dikarenakan sulfur di dalam bahan yang tidak terikat dengan senyawa lain akan mengalami terikat dengan oksigen mengalami oksidasi dan menguap, sehingga kandungan senyawa sulfurnya menjadi berkurang. Belerang yang dihasilkan dari aktivitas vulkanik berupa belerang dioksida atau sebagai hidrogen sulfida, yang dapat teroksidasi menjadi belerang dioksida dan sulfat di atmosfeer. Sulfida-logam sukar larut dalam air tetapi setelah teroksidasi menjadi logam-sulfat relatif lebih larut dalam air. Di tanah dan di air, sulfat diubah menjadi belerang organik oleh tanaman dan bacteria. Bakteria berperanan dalam transisi antara sulfat, belerang, belerang organik dan hydrogen sulfida. Belerang (II) lepas ke atmosfeer sebagai $\mathrm{H} 2 \mathrm{~S}$ atau senyawa organo belerang yang volatile, atau mengendap sebagai sulfida logam (Sopiah 2005).

Kadar lemak meningkat dalam keripik kangkung. Dengan berkurangnya air pada bahan, maka minyak akan mudah terserap ke dalam bahan pangan sehingga menyebabkan kadar lemak meningkat. Suhu penggorengan yang tinggi pada keripik dapat menyebabkan permukaan bahan terdehidrasi sehingga menyebabkan penetrasi minyak ke dalam bahan menjadi lebih banyak (Tumbel dan Manurung 2017).

Dari hasil pengamatan diketahui bahwa kadar protein didalam bahan terjadi peningkatan setelah penggorengan yakni sebesar 1,84\%, dikarenakan dalam penggorengan dilakukan penambahan bahan pendukung lain seperti tepung, telur, kemiri yang banyak mengandung protein. Hal ini juga berdampak pada kandungan karbohidrat yang meningkat setelah dilakukan penggorengan yakni sebesar $3,58 \%$ dikarenakan adanya penambahan bahan pendukung lainnya yang mengandung kadar karbohidrat. Kandungan protein kemiri sebesar 19 gram dan kandungan karbohidrat sebesar 8 gram dalam 100 gram bahan (Ketaren 2008), sedangkan menurut Direktorat Gizi Departemen Kesehatan R.I (1996), tepung terigu memiliki kandungan protein dan karbohidrat masing-masing sebesar 8,9 gram dan 77,3 gram bahan dalam 100 gram bahan. Kandungan protein dan karbohidrat dalam adonan pembuatan keripik kangkung belerang akan menyerap ke dalam kangkung selama proses penggorengan sehingga menyebabkan kandungan protein dan karbohidrat meningkat.

Dari hasil pengamatan tabel 2, bahwa umur simpan mempengaruhi 
peningkatan bilangan peroksida. Hal ini dikarenakan terjadinya oksidasi terhadap ikatan rangkap yang terdapat dalam minyak atau lemak pada bahan sehingga menjadi lemak jenuh. Peningkatan angka peroksida diakibatkan proses oksidasi pada proses pemasakan atau pemanasan minyak goreng. Oktaviani (2009) menjelaskan bahwa bilangan peroksida meningkat disebabkan karena pemanasan terhadap minyak curah. Pada hari ke-15, keripik kangkung belerang, bertekstur tidak rapuh dan tengik. Daya simpan akan mempengaruhi jumlah kadar air dalam keripik, sehingga menyebabkan kelembapan keripik meningkat. Hal ini dapat mempercepat proses oksidasi dalam bahan pangan sehingga bilangan oksidasi dapat meningkat. Hal ini juga diakibatkan penyimpanan keripik kangkung belerang yang kurang tepat sehingga menyebabkan proses hidrolisis semakin cepat. Tarigan $e t$ al. (2007) menyatakan bau tengik pada minyak disebabkan oleh asam lemak bebas yang dihasilkan selama proses hidrolisis. Proses hidrolisis dapat dipercepat dengan kondisi kelembaban yangtinggi, suhu yang tinggi, serta kandungan air yang tinggi. Peroksida dapat mempercepat proses timbulnya bau tengik dan flavor yang tidak dikehendaki dalam bahan pangan (Aminah 2010).

Dari hasil pengamatan tabel 3. diatas dapat disimpulkan bahwa dari 20 orang panelis, menilai produk kripik kangkung belerang dengan menggunakan minyak curah sebesar $85 \%$ menyukai aroma, dan rasa dari produk tersebut, sedangkan terhadap warna produk itu sendiri mendapat $80 \%$ penilaian dari panelis. Aroma merupakan salah satu variabel kunci, karena pada umumnya citarasa konsumen terhadap produk makanan sangat ditentukan oleh aroma. Aroma makanan banyak menentukan kelezatan makanan serta citarasa bahan pangan itu sendiri (Wellyalina et al. 2013). Menurut Kartika (1988), dalam industri pangan pengujian terhadap aroma dianggap sangat penting karena dengan cepat dapat menghasilkan penilaian terhadap produk tentang diterima atau ditolaknya produk tersebut. Menurut Lestari et al. (2015), bahwa aroma pada keripik kangkung rasa paru banyak dipengaruhi oleh bumbubumbu yang dipergunakan yaitu bawang putih, ketumbar dan kemiri. Penilaian terhadap tekstur dari keripik kangkung belerang, oleh 20 orang panelis memberikan penilaian berupa tekstur yang renyah. Bahan pangan yang di goreng mempunyai rasa yang lebih gurih karena adanya serapan minyak ke bahan. Kualitas minyak sangat berpengaruh terhadap rasa gorengan, komponen dalam minyak akan masuk ke bahan (Aminah 2010). Menurut Choe dan Min (2007) pada suhu dan waktu yang optimum, penggorengan akan menghasilkan warna coklat keemasan, krispi dan absorpsi minyak optimum.

\section{KESIMPULAN}

Hasil analisis kimia menunjukkan bahwa kadar air, kadar abu, kadar sulfur, kadar lemak, kadar karbohidrat, kadar protein dan bilangan peroksida meliputi $0,15 \% ; 87,64 \% ; 54,25 \% ; 6,75 \% ; 5,01 \%$; $14,31 \%$ dan $7,18 \mathrm{meq} / \mathrm{kg}$.

Peningkatan bilangan peroksida terjadi selama masa penyimpanan pada produk keripik kangkung belerang sehingga disarankan untuk menyimpan keripik kangkung belerang pada tempat yang tidak terpapar matahari sehingga dapat menambah daya simpan keripik kangkung belerang. Dari penilaian uji hedonik dapat disimpulkan bahwa produk kripik kangkung belerang dengan menggunakan minyak curah ini dapat dipasarkan dan disukai oleh konsumen.

\section{UCAPAN TERIMA KASIH}

Ucapan terimaksih kepada DRPM KEMENRISTEKDIKTI yang telah memberikan Hibah Penelitian Dosen Pemula tahun 2018. 


\section{DAFTAR PUSTAKA}

Aminah S. 2010. Bilangan peroksida minyak goreng curah dan sifat organoleptik tempe pada pengulangan penggorengan. Jurnal Pangan dan Gizi. 1(1).

Asmawit, Hidayati. 2014. Pengaruh suhu penggorengan dan ketebalan irisan buah terhadap karakteristik keripik menggunakan penggorengan vakum. Jurnal Litbang Industri Padang. 4(2): 115-121.

Choe E, Min BD. 2007. Chemistry of Deep-Fat Frying Oils. Journal of Food Science. 72 (5).

Direktorat Gizi Departemen Kesehatan Republik Indonesia. 1996. Daftar Komposisi Zat Gizi. Pangan Indonesia. Jakarta (ID): Departemen Kesehatan RI

Kartika B., Hastuti P, Supartono W. 1988. Pedoman Uji Inderawi Bahan Pangan. Yogyakarta (ID): Universitas Gajah Mada.

Ketaren S. 2008. Minyak dan Lemak Pangan. Cetakan Pertama. Jakarta (ID): Universitas Indonesia Press.

Lestari S, Astuti Y, Muttakin S. 2015. Kerpik kangkung rasa paru sebagai produk olahan guna meningkatkan nilai tambah. Prosiding Seminar Nasional Masyarakat Biodiversitas Indonesia. 1 (7).
Oktaviani. 2009. Hubungan lamanya pemanasan dengan kerusakan minyak goreng curah ditinjau dari bilangan oksidasi. Jurnal Biomedika. 1(1): 31-35.

Sopiah N. 2005. transformasi kimia senyawa belerang, dampak dan penanganannya. jurnal teknik lingkungan. P3TL-BPPT. 6 (1): 339343.

Tarigan, Nurhayati, Oppusunggu. 2007. Pengaruh penyuluhan kepada pedagang gorengan dengan angka peroksida dan asam pada minyak goreng. Jurnal Ilmiah PANNMED, 2(1): 20-28.

Tumbel N, Manurung S. 2017. Dampak temperatur dan waktu penggorengan terhadap kualitas keripik nenas menggunakan penggorengan vacum. Jurnal Penelitian teknologi Industri. 9(1): 9-22.

Wellyalina, Azima F, Aisman. 2013. Pengaruh perbandingan tetelan merah tuna dan tepung maizena terhadap mutu nugget. Jurnal Aplikasi Teknologi Pangan. 2 (1): 916.

Winarno FG. 2004. Kimia Pangan dan Gizi. Jakarta (ID): PT. Gramedia Pustaka Utama. 